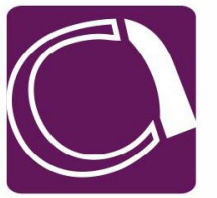

ENSAYO

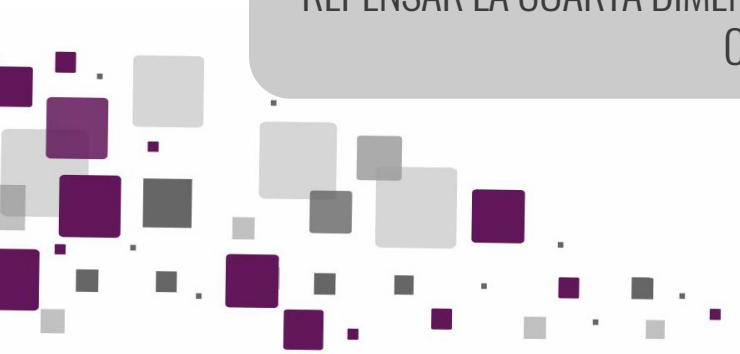

\title{
RETHINKING THE FOURTH POWER DIMENSION: ORGANISATIONAL SUBJECT AND CULTURE CHANGE
}

\section{REPENSAR LA CUARTA DIMENSIÓN DEL PODER: SUJETO ORGANIZACIONAL Y CAMBIO CULTURAL}

\section{Abstract}

This paper aims to rethink the view of the fourth power dimension, alongside the idea of the organisational subject and cultural change. This work is a theoretical review divided into six parts. The first section is an introduction regarding the discussion of power in the first three dimensions. The second part deals with the fourth power dimension. The third part reflects upon the ethical subject. The fourth section approaches the study of power in organisations, and the fifth part delves into the proposal of the organisational subject. The sixth part links the idea of the organisational subject to culture change. Finally, a series of reflexions are proposed about the possible ways to study the organisational subject.

Key words: culture change; ethical subject; organisational studies; power.

\section{Resumen}

El objetivo de este ensayo es repensar la perspectiva de la cuarta dimensión del poder, con ayuda de la idea del sujeto organizacional y el cambio cultural. El presente trabajo es una revisión teórica dividida en seis partes: la primera sección es una introducción con respecto a la discusión del poder en las primeras tres dimensiones; la segunda parte habla acerca de la cuarta dimensión del poder; la tercera parte es una reflexión acerca del sujeto ético; la cuarta sección es una aproximación al estudio del poder en las organizaciones; el quinto apartado profundiza en la propuesta del sujeto organizacional; el sexto apartado vincula la idea del sujeto organizacional y el cambio cultural. Finalmente, se proponen una serie de reflexiones con respecto a posibles caminos de estudio del sujeto organizacional.

Palabras clave: cambio cultural; sujeto ético; estudios organizacionales; poder.

- ERIK GEOVANY GONZÁLEZ CRUZ https://orid.org/0000-0003-1560-5830 erikgeovany.gc@gmail.com

División de Ciencias Socialesy Humanidades. Universidad Autónoma Metropolitana. México. 
-

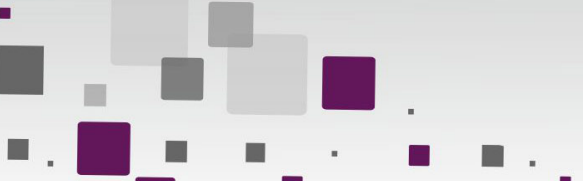

Introduction

The study of power in a global perspective is becoming mainstream in sociology and political sciences, and it is an important theme in the analysis of organisations, especially in the modern era with the rise of large companies and organisations. There are multiple ways to approach its study, each with some particular feature or contribution, making power research complex as a social phenomenon. This fact is important as it evolves from Machiavelli's philosophy (1999) and the train of thought by Hobbes (1998), Locke (1990), and Rousseau (1994). However, Marx (1999) and Weber (1995) represent a shift in power thinking, caused by the rise of large organisations and the triumph of the social (Arendt, 2017).

In this path to study power, sociologic and scientific perspectives have strengthened, and a new branch is born from sociology, the political sciences, especially responsible for studying power. Researchers then work to understand and measure this phenomenon's systematicity and the three dimensions built. Nevertheless, a fourth dimension is proposed which, apart from measuring it, seeks to explain power deeply. This creates a series of contradictions and problems between systematic power supporters and highly-restrictive power believers. Within the fourth dimension, there is an element that has been little addressed: the subject. The objective of this work is to revisit the fourth power dimension through the subject and the organisational subject as the element showing the process of the domination towards liberation and, in this way, the rise of an actor and their participation in cultural change.

For this purpose, the first section will address the three power dimensions by Dahl (1957), Barach and Baratz (1962), and Lukes' criticism (1984) over the first two dimensions. In the second part, we will discuss the fourth power dimension, coming from Foucault's thoughts $(1988 ; 2002 ; 2008$; 2012); in addition, the two views of the subject will be differentiated. The next section places special emphasis on the second view of the subject - the ethical subject. The fourth section exposes some works about power in organisations, taken from the revised four dimensions. Following this perspective, we address the concept of an organisational subject from Foucault's contributions $(1988 ; 2005)$ and their place in organisational studies. The sixth section relates the organisational subject to cultural
Año 9 | Nº 18 Julio - Diciembre 2021 | ISSN 2314 - 3738

Erik Geovany González Cruz change (Alvesson, 2016; Deetz, Tracy \& Simpson, 2000) through Courpasson and Dany's work (2009). Finally, we devote time for reflection upon the study of the subject in an organisation, considering a submissive and emancipated subject.

In line with this, the study of the subject in organisations is scarce, although not necessarily new. We can observe the characteristics of the subject regarding power, particularly in the power's fourth dimension. However, revisiting the first three dimensions gives the basis to distinguish the kind of power that Foucault refers to.

\section{Three Power Dimensions}

Machiavelli (1999), Hobbes (1998), Locke (1990), and Rousseau (1994) consider power as a bidirectional relationship between the community and who holds power. In this sense, each person in the community gives part of their freedom (to survive, for the good of everybody) to one person or assembly, and this person o or assembly exercises this power over the community. In Weber (1995) and Marx (1999), this is part of a political philosophy, changed due to new large organisations and power, to now being considered a social relationship. This was very important because the social sphere combined the public and private spheres (Arendt, 2007), resulting in social as the base for studies and science as the knowledge method. Then, the way of seeing power change was no longer philosophical but scientific, which would systematically seek to measure power.

In The Concept of Power, Dahl (1957) develops a way to systematically study power for he defines it as " $A$ has power over B to the extent that he can get $B$ to do something that $B$ would not otherwise do" (Dahl, 1957, pp. 202-203). This concept allows using variables and permits the measurement of the amount of power exercised over $B$, as well as the resistance this can express.

In this view, Bachrach and Baratz (1962) make a criticism to the elitist and populist vision of power, concluding that power is not ordered; it is stratified. A second criticism comprised the idea that power does not hold in time and the third aspect expresses that one exercising power has got no control over results or effects. In other words, power is not a closed system. The next quote further shows why the study of power is so complex:

Of course power is exercised when A participates 
in the making of decisions that affect $B$. But power is also exercised when A devotes his energies to creating or reinforcing social and political values and institutional practices that limit the scope of the political process to public consideration of only those issues which are comparatively innocuous to $A$. To the extent that A succeeds in doing this, B is prevented, for all practical purpose, from bringing to the fore any issues that might in their resolution be seriously detrimental to A's set of preferences. (Bachrach \& Baratz, 1962, p. 948)

This use of social and political values and institutional practices for exercising power is paramount because it reflects that power is exercised indirectly. Lukes (1984) refers to this as bias mobilisation and criticises this perspective, proposing the third dimension.

Lukes (1984) takes on Dahl's definition of power and calls coercion to Bachrach and Baratz's concept as he considers that Bachrach y Baratz's perspective creates confusion. Moreover, Lukes criticizes the analysis of the second face of power to the first dimension regarding this behavioural perspective, considering that the second face is also behavioural. That is to say, one exercising power in the second face has got control over the effects or results of this fact. In consequence, Lukes defines power as follows:
The three-dimensional view of power involves a thoroughgoing critique of the behavioural focus of the first two views as too individualistic and allows for consideration of the many ways in which potential issues are kept out of politics, whether through individual's decisions. This, moreover, can occur in the absence of actual, observable conflict, which way have been successfully averted - though there remains here an implicit reference to potential conflict. This potential, however, may never in fact be actualised. What one may have here is a latent conflict, which consists in a contradiction between the interests of those exercising power and the real interests of those they exclude. (Lukes, 1984, pp. 24-25)

Lukes differentiates between the first, the second, and the third dimension using the next aspects (Table 1):

In the abstract, the differences between the three dimensions are the grade of critique to the behavioural focus and the decision-making or nondecision-making, the observable or latent conflicts, and the form of the interest. Lukes "defined the concept of power by saying that A exercises power over B when A affects B in a manner contrary to B's interests" (1984, 34), and he mentions three characteristics of the three dimensions of power: 1 ) inaction is an element of power as well as action;

Table 1

Differences between the dimensions of power from Lukes

\begin{tabular}{|c|c|c|}
\hline $\begin{array}{c}\text { First -Dimensional View of } \\
\text { Power }\end{array}$ & $\begin{array}{c}\text { Second-Dimensional View of } \\
\text { Power }\end{array}$ & $\begin{array}{l}\text { Third-Dimensional View of } \\
\text { Power }\end{array}$ \\
\hline $\begin{array}{l}\text { Focus on:-Behaviour. } \\
\text {-Decision-making. } \\
\text {-(Key) issues. } \\
\text {-Observable (overt) conflict. } \\
\text {-(Subjective) interests, seen as } \\
\text { policy preferences revealed by } \\
\text { political participation. }\end{array}$ & \begin{tabular}{|l|} 
(Qualified) critique of \\
behavioural focus. \\
Focus on: \\
-Decision-making and \\
nondecision-making. \\
-Issues and potential issues. \\
-Observable (overt or covert) \\
conflict. \\
-(Subjective) interests, seen \\
as policy preferences or \\
grievances.
\end{tabular} & $\begin{array}{l}\text { Critique of behavioural focus. } \\
\text { Focus on: } \\
\text {-Decision-making and control } \\
\text { over political agenda (not } \\
\text { necessarily through decisions). } \\
\text {-Issues and potential issues. } \\
\text {-Observable (over o covert) and } \\
\text { latent conflict. } \\
\text {-Subjective and real interests. }\end{array}$ \\
\hline
\end{tabular}

Note. Lukes (1984). Power a radical view. Hong Kong: Macmillan. 
2) this can be unconscious, and 3) power can be exercised by communities as groups or institutions.

From this dimension rises systemic power.

The three dimensions focused in the exercise of power prefer a measuring way, with different elements. On the other hand, Foucault develops a series of ideas seeking to describe how power is exercised. In other words, it is not about knowing how much power but how it is exercised. Also, what are the effects on people. This creates the fourth dimension of power.

\section{The Fourth Dimension of Power}

The fourth dimension of power is based on Foucault's philosophy and comprises two parts. The first part deals with the subject submitted to others and themselves, and the second part deals with the subject in the process of obtaining freedom -it is the subject conscious of their reality and themselves. Within the study of organisations, the first part is studied the most and relates to how power is exercised over others and one-self.

In The archaeology of the knowledge (2008), Foucault shows how power is wielded. Power is part of a structure of discursive forms, which builds, transforms, and changes the interpretation of reality resulting in the truth. Foucault searches to base it on the study of History but from a genealogic point of view:

There was a time when archaeology, as a discipline of silent monuments, of inert traces, of objects without context and of things left by the past, tended to history and did not acquire meaning except by the restitution of a historical discourse; it could be said, playing a little with the words, that, in our days, history tends towards archaeology, to the intrinsic description of the monument. (Foucault, 2008, p. 11)

The difference with the History genealogic perspective is the search for jumps, deviations, crossings, and limits in telling facts. History is told through speech, but this involves the speech from who can say and the speech from who cannot say.

The manifest discourse would not be in the end more than the repressive presence of what it does not say, and that "not said" would be a void that undermines everything that is said from within. The first reason makes the historical analysis of the discourse is searching and repetition of an origin that escapes all historical determination; the other makes it an interpretation or listening to an "already said" that would be at the same time a "non-said" (Foucault, 2008, p. 40).

Power moves through speech, so power carries a purpose that is not the body but the soul. Foucault (2002) describes the exercise of power over bodies to souls when he talks about torture and how this explicit violence over the body of the punished is exercised intrinsically over witnesses, though it is still direct violence. If the prison system replaced old practices, bodies would be in the middle of the new objective of power. In other words, disciplinary control over bodies in prison also affects the soul of the punished.

No longer touching the body, or at least possible in any case, and that to wound in him something that is not the body itself [...] The body is here in a situation of instrument or intermediary [...] Since it is no longer the body the soul. To the explanation that causes havoc in the body must happen a punishment that acts in depth on the heart, thought, will, dispositions (Foucault, 2002, pp. 18-24).

Foucault's perspective on power gives a twist. As Lukes pointed out, Dahl, Bachrach and Baratz had conceived power from a behavioural perspective, a little in the latent conflict that he speaks about. You can observe the hidden power and communities as elements exercising power. However, Foucault raises a theoretical framework of power operations and this new element -the soul as a victim of the exercise of power, is not the relationship of one individual with another or between communities; it is the individual or the assembly over the soul of the one who is punished through their body. Therefore, a power relationship of another type emerges - the subject is the object of power. In this sense, Foucault says, "the general theme of my research is not the power but the subject" (Foucault, 1988, p. 3).

This is how power should be analysed - by its resistances. Instead of "its internal rationality, it is about analysing power relations through the confrontation of strategies" (Foucault, 1988, p. 5). Resistance comes from the subject, who, 
at first glance, has two meanings: the one who is "subjected to another through control and dependence and the subject tied to its own identity by consciousness or knowledge of itself" (Foucault, 1988 , p. 7). The other meaning is described by Foucault in The hermeneutics of subject (2005) and includes the relationship the subject maintains with the truth, coming first from the Greek thought epimeleia heautou, "the concern of oneself, the fact of worrying about oneself, worrying by itself, etc." (Foucault, 2005, p. 15) and later from the Cartesian thought gnothi seauton, to know yourself. This deals with the liberation of the subject from the submission of others and themselves. The subject theme is very important, especially the subject in process of liberation. Then, this gives full shape of the fourth dimension.

\section{Subject}

The subject character has got two shapes in Foucault's thought (1988; 2002; 2005; 2012). The first one is a subjected subject, and the other one is a self-subjected subject. The idea of the subject comes from the philosophic division between the outside and the inside - the division of object and subject. There is an element of modern thought in this subject perspective, born with what Foucault (2005) calls "cartesian movement".

The Cartesian movement is the onset of empiricist knowledge, replacing epimeleia heautou with gnothi seauton (Foucault, 2005). This means that the step to access truth is now outside the person, through their senses. Before, the individual could access the truth of their own being. Foucault (2005) exposes that gnothi seauton in ancient Greek thought was a Delphic precept whose meaning included epimeleia heautou. It was an invitation for self-reflection and especially, an invitation to those approaching the oracle, who were usually governors or influential people, to know their destiny. The invitation then is to know yourself deeply and internally.

Meanwhile, epimeleia heautou is most clearly distinguished in Socratic thought, and it is the practice of soul care. Now, the division of body and soul is recognized. In this sense, the access to truth is inside each one. Foucault (2005) calls this ascetic movement, the elevation of the soul towards the truth.
The subject of self-concern has, if you prefer, an early philosophical formulation that appears clearly from the $V$ century b.C., a notion that crossed, until the IV and V centuries a.C., all Greek, Hellenistic and Roman philosophy, as well as the Christian spirituality. Finally, with this notion of epimeleia heautou we have a whole corpus that defines a way of being, an attitude, forms of reflection, practices that make it an extremely important kind of phenomenon, not only in the history of representations, not only in the history of ideas or theories, but in the history of subjectivity itself or, if you prefer, in the history of the practices of subjectivity. (Foucault, 2005, p. 26-27)

In the Cartesian movement the existence of the soul was denied. Therefore, its care was left adrift. At this moment is when the modern subject arises, they have been denied the ability to access the truth for themselves. The modern subject depends on others to know the truth because the truth now belongs to the power mechanisms (Foucault, 2002). It is all about the subjected subject.

The subjected subject is objectified as long as the discourse of the outside is internalised and they become an object (or phenomenon) - an object of study, analysis, and scrutiny. However, not an urging of the soul of the being. Meanwhile, in the eyes of Foucault (2005), the self-subjected subject relates to self-care, self-restlessness, in other words, to the epimeleia heautou. It is an ethical subject.

In an organisation, the ethical subject is the organisational subject. The idea is to know and promote this study in the field of organisation studies. In this case, we can combine the power and culture issue with the organisational subject. In this line, the next section will review what has been done from the power perspective in organisations, alongside with the four dimensions.

\section{Power in Organisations}

Lukes offered an important way of seeing power in general, but also with respect to organisations in particular. Hardy (1994) recognizes four dimensions of seeing power; these are: "decision-making power, non-decision-making, symbolic power, and systematic power" (Hardy, 1994, p. 220). In this sense, the first three dimensions belong to those developed by Lukes, and the fourth dimension 
proposed by Hardy is that of power systems, belonging to Foucault's thought in the sense of subjection, an exercise of invisible and unconscious power. However, this approach to the four power dimensions leaves aside Foucault's free subject, which is an important part in the fourth dimension of power, and that is explained only by understanding the levels of power exercise referred to by Hardy.

Digeser (2012) does something similar in his work The fourth face of power. The first three faces correspond to Lukes' first three power dimensions, and the fourth emanates from Foucault's thought. However, Digeser pays special attention to the subject, firstly, in such a way that it is "understood as a social construction, whose formation can be historically described" (Digeser, 2012, p. 223), and secondly, in the sense of resistance, as a result of the previous and where the power exercise is more visible:

Where resistance is greatest, the exercise of power may be clearest. And so Foucault writes histories of the most visible forms of resistance: the mad, the sick, the criminal, and the abnormal. These histories reveal the constructed nature of subjectivity as well as kind of subject we have become. Their histories give us a sense of our own "subjectification" and of the costs that must be incurred in becoming a "normal" subject. (Digeser, 2012, p. 228)

Digeser (2012) compares two ways of conceiving power. On the one hand, a liberal vision, involving the agent's thought as an element of the power phenomenon: "within the radical and liberal conceptions of power there is always the possibility for human relationships not to be mediated by power. This is not true for the omnipresent fourth face" (Digeser, 2012, p. 224). That is to say power is so internalized that it is a new type of power, one that is not possible to see, only in the resistance and conflict processes.

Digeser (2012) managed to perceive, in The fourth face of power, something that Hardy (1994), in Power and politics in organizations, left aside. The subject resists to give a functional sense to Foucault's vision. I do not mean the subject is bound by this omnipresent power that is systematic and invisible as Digeser and Hardy respectively point out, but the liberated subject, the one who goes through the process of self-knowledge, the search for truth as a process of liberation. Digeser
Año 9 | Nº 18 Julio - Diciembre 2021 | ISSN 2314 - 3738

Erik Geovany González Cruz raises this knowledge and power relationship but does not make it explicit, something that Foucault worked on in the last stage of their studies. This is important, because it provides an overview of the path taken by the study of power in organisations and its proximity to the four power dimensions in the sense proposed in this work, implying the free subject - the one who resists.

Clegg (1990) takes up the idea of agency and organisation as a partly constructivist tendency and affirms, in this way, that "control can never be totally secured, in part because of agency" (Clegg, 1990, p. 193). Along this line, Clegg raises the issue of power circuits, which involves a three-level analysis: agency, social integration, and system integration. These power circuits demonstrate different forms in which power is exercised and its systematization process. Up to this point, we could say that Clegg talks within the four dimensions of power; however, he excludes Foucault's in-depth subject study, taking it back only in a systematic way. He even makes it evident by stating that "Parsons (1967) and Foucault (1977) have distinctly different (albeit with some family resemblance to each other) conceptions of power to the agency conception which has been the mainstream" (Clegg, 1990, p. 239). This fact is repeated by several important authors within the study of power in organisations. Hardy and Clegg (1996) highlight it by raising two perspectives of studying power: a functionalist, where power has a managerial perspective - that is, good when they use it and bad when used by their opponents - and another, a critique that sees power as a means for domination and resistance.

Ironically, the power/knowledge concept of Foucault has robbed this body of work of much of its emancipatory power, and many writers (e.g. Alvesson and Willmot 1992; Knights and Vurdubakis 1994) seem to be struggling to give the postmodern adaptation back its modernist edge. The majority of the work is, however, highly theoretical, often ignoring the practicalities of developing strategies for resistance and liberation. (Hardy \& Clegg, 1996, p. 636).

The last quote exposes a confrontation of the current perspective of the study of power and an evident reduction of the Foucauldian thought. However, the actor's role cannot be understood without understanding the power complexity, as 
Foucault proposed. This is evident in the way in which authors reflect upon and systematize it. Nevertheless, they reduce its complexity and depth to the sole observation of power, that complexity that takes the subject away from their freedom, but also gives them the possibility of becoming free, and in this sense, becoming an actor within the organisation.

Crozier and Friedberg (1990) focus on the actor and their relationship with the system within organisations. The actor is an element participating in the dynamics of the organisation, although limited there. A piece of constructivist thought exposes an overvaluation of "the rationality of the functioning of organisations" (Crozier \& Friedberg, 1990, 35), leading "to manifest exaggerated fears before the threat of oppression that could represent for men" (Crozier \& Friedberg, 1990, p. 35). In this sense, the authors propose the following regarding the actor:

The actors have only a restricted freedom and are only capable, correlatively, of a limited rationality. In other words, the actors - their freedom and their rationality, their objectives and their "needs" or, if required, their affectivity - are social constructs and not abstract entities. Starting from this, the problem is no longer that of the chosen model of explanation, but the one of the research approach that will allow to discover the material, structural and human conditions of the context, which limit and define this freedom and this rationality, and hence, the sense of empirically observable behaviours. (Crozier \& Friedberg, 1990, p. 46)

In this sense, the analysis carried out by Crozier and Friedberg (1990) starts from two types of reasoning: strategic reasoning and systemic reasoning "that are complementary, contradictory and convergent at the same time" (Crozier \& Friedberg, 1990, p. 191). On the one hand, strategic reasoning arises from the actor; however, as it was already mentioned, the actor has limited freedom; this is simultaneous and is determined by systemic reasoning.

The systems in which we think are also constructs, not formalized, whose rules are absolutely empirical and whose actors, although they are more or less intuitively aware of the results, completely ignore the mechanisms and, therefore, are unable to control or influence in them. (Crozier \& Friedberg, 1990, p. 188)

The actor is the result of the liberation of the subject within the organisation. The liberty acquired is the key that allows opening the system. Because if there is no process of subject liberation submitted, the actor does not make any sense. That is why it is important to study the organisational subject for leading an in-depth discussion of the system operations.

A way of understanding the organisational subject is through cultural change; specifically, the case of Jean Paul presented by Courpasson and Dany (2009). Here, we can observe the interaction between the power embedded in the narrative of organisation, the attempt to change the organisation's culture through the negative narrative and the organisational subject alongside the resistance process that the authors make evident.

\section{The Organisational Subject}

The organisational subject cannot be conceived in itself, but the relationship between gnothi seauton and epimeleia heautou during the ancient times, the prioritization, requalification, and redefinition of gnothi seauton in modern philosophy, and the discussions between modernity and postmodernity are understood. Understanding that the subject is a subject dominated by others and by their own thoughts, and that they can be liberated through critical theory, but also from philosophical and ethical positions of the individuals themselves.

The organisational subject is the phenomenon that occurs when a subject dominated in an organisation either by others or by themselves, within the complexity that involves systematic, discursive, and symbolic domination, becomes an ethical subject capable of truth by themselves and aware of the domination in which they are and has got the ability to liberate themselves. The ethical subject within an organisation is capable of using its strategic reasoning and is aware of its systemic reasoning; that is, it has the possibility of becoming an actor in the organisation (Crozier \& Friedberg, 1990).

The character of the organisational subject within the organisational studies is part of the postmodern tradition. Several works already take 
-

up the idea of the subject in the organisations from Foucault, for example, Munro, I. (2014); Skinner, D. (2012); Bardon, T. \& Josserand, E. (2010). However, the organisational subject moves between submission and liberty through the complex discursive organisation dynamics and the people's subjectivities there. It is like watching power as a tide that comes and goes inside organisations, and people are sea transporting it from one place to another.

In this regard, Byung-Chul Han (2017) pays special attention to communicative action of power. The author sees it as the continuation of the self in the other and the return to the self. It is the will of the ruler over the other, but without losing themselves in the otherness. However, Han (2017) analyses the power of the person exercising it, in opposition to Foucault, who pays attention to the person on whom it is exercised. In this sense, both authors agree on the danger of getting lost in the other and the need to go back to oneself. This moment is particularly important because it is the moment of communion between the governed and the governor. It is the moment for the organisational subject's and ethical organisation's wills to agree on and create an organisation. Nevertheless, this is a difficult thing to happen, and it is more likely to generate conflict and, in the end, this conforms to the culture of organisations.

\section{The Organisational Subject and Cultural Change}

The organisational subject is a form of understanding the second part of the fourth dimension of power. It is very important because the subject in the organisation, like several authors point out, is the organisation's constructor and builder. In other words, the organisation is in the process of constant change. It can be the result of external or internal forces, triggering changes in the organisations (Alvesson \& Sveningsson, 2016). The organisational subject is an element of the internal change to both participate in and resist change.

Deetz, Tracy, and Simpson (2000) propose two forms of culture change, on the one hand, the change coming from within, a profound change of values. The key aspect is that there are changes in habits and actions in organisations, but first changes to the internal values and belief structures of employees. On the other hand, the change from outside, when the behaviour, actions, and external communication patterns organise and form internal values and beliefs. In this sense, daily habits, communication patterns, and proposed objectives must be changed first. The organisational subject is at the first level of change. Still, authors talk about the complexity of cultural change because "culture is an endless negotiation by organisational members. Activities and interactions are part of the development of shared interpretations and common assumptions" (Deetz, Tracy \& Simpson, 2000, p. 42 ). By considering the organisational subject, this makes the researcher approach extremely complex but not impossible.

Courpasson and Dany (2009) give an example of the depth with which power relations should be studied, from the fourth dimension of power to cultural change and resistance in the organisation. They conduct a study about a worker (Jean Paul) who decides not to accept a promotion at work, triggering a series of effects beginning with Jean Paul's resignation from the company and the change of practices in the promotion process within the organisation. This involved a decision-making process by Jean Paul, where he weighed different spheres of his life and made a decision that went against the construct of the organisation's discourse, which can be called subjectification, and which is an element of the fourth dimension of power and, in particular, of the free subject.

The fourth face of power is identified as subjectification, a state which occurs when actors are attached to a form of identity which is actually derived from a structure of domination, (see also Hardy and Leiba-O'Sullivan 1998). Seeing subjects as being in a state of subjectification is a departure from traditional visions in which resistance is identified with overt 'industrial struggles' (Fleming and Spicer 2007, p. 42). The fourth face of power, conceived as subjectification, opens the way to more various and ambiguous forms of subversion. (Courpasson \& Dany, 2009, 337).

In this example, the subject was submitted to the organisational decision, and the natural choice was accepting the promotion because this is the speech of the organisation and part of their corporative culture. However, when Jean Paul chose to refuse the promotion, that went against the expected behaviour. And this meant a change in the promotions process. In other words, Jean Paul 
is not constructed by the corporative culture, or if he is, he broke this structure when he evaluated different perspectives of his life and not only the organisational one. This could be an example of the free subject, resulting in a break with the organisation and a change in the organisation, because it had the need to control the staff for promotions, so the organisation changed the form of its process, that is to say, it changed the mechanism of power.

Jean Paul indirectly modified the practices belonging to the corporative culture of the company with his decision. The organisation generated a negative narrative around Jean Paul's choice to avoid this type of behaviour. In this case, the organisation (and actually some important people) failed to create a common power. "For Hegel, the power of the spirit is based on generating an "us", a community, a continuity of the general and the common to everybody" (Han, 2017, 125).

The neoliberal subject (Han, 2014) is different from the organisational subject. The neoliberal subject is submitted and needs the other, the outside, to be free, whereas the organisational subject arises from submission and has possibilities of liberation through an internal breakdown of his subjectivity - the government of the self which gives way to the government of others (Gros, 2005).

However, there are still some unanswered questions: Why Jean Paul refused the offer and other people did not? What has Jean Paul got that the others persons do not have? Moreover, how can the organisation know how to identify one out of the rest and act accordingly? For this, it is important to go deep in understanding the subject in the process of liberation. Definitely, this is not about avoiding it because it can generate more resistance and psychologic problems to people. Rather, it is to generate authentic organisational actors and a strong organisational culture. In this case, power would finally be constructive for everybody, something that Machiavelli, Hobbes, Locke, and Rousseau thought.

\section{Conclusions}

Power is a theme in sociologic studies. This work exposes how power perspectives change the first view from the politic philosophy and a second moment to sociologic philosophy. This change is significant because the reason that maintains the course of reflections about power changed. Power as the capacity to govern emerges from a general power of people to give way to the concept of power as a social relationship. And the scientific perspective guided and currently guides the study of power.

In this perspective, the four dimensions of power explain the phenomenon: the first dimension talks about the power over others and the possibility of resistance; the second dimension addresses the use of social and political values and institutional practices for exercising power; the third dimension is key to the behavioural focus of the first and the second dimension, and the recognition of the systemic power.

The fourth dimenion is given special treatment because we suggest two parts for this dimension. Firstly, power which submits people and people's souls through speech and body control. This is the traditional perspective of power by Foucault; in other words, the subject submitted to others and oneself. However, the focus of the second part is the subject in the process of liberation, and this process is the forgotten element, but it is the main theme of study for us in organisational studies.

In this direction, the study of power in the organisations has left aside the ethical subject or the subject in the process of liberation. Studies have regularly retaken only one part of the fourth dimension of power, the part of the subject submitted to others and to one-self and the proposal that systematic power has been strengthened. In the same way, it is a jump to the organisational actor but without going deeply into the organisational subject.

The study of the organisational subject is very important for the topic of change and especially for the topic of power in organisations. This provides a better view of the multiple complexities of the organisational phenomenon. The organisational subject can be studied from the point of view of anthropology, psychology, economy, political sciences, etc. But the perspective of power allows understanding very well their function, their movement and, specially, completing the idea of a system to have a better understanding of this.

The organisational subject opens a field capable of delving into the human being in organisational studies. The case of Jean Paul allowed for the observance of the organisation's behaviour after rejecting the promotion. The attempt to control its corporative culture with a 
negative narrative resulted from Jean Paul's selfsubjectivation and traces the phenomenon of the organisational subject. This can lead to conflict, but also to ethical organisations where power is a shared will and not an induced one.

\section{References}

Alvesson, M. \& Sveningsson, S. (2016). Changing organizational culture: Cultural change work in progress. London: Routledge.

Arendt, H. (2017). La condición humana. México: Paidós.

Bachrach, P. \& Baratz, M. (1962). Two face of power. The American Political Science Review, 56 (4), pp. 947-952. https://doi.org/10.2307/1952796

Bardon, T. \& Josserand, E. (2010). A Nietzschean reading of Foucauldian thinking: constructing a project of the self within an ontology of becoming. Organization, 18(4), pp. 497-515. https://doi. org/10.1177/1350508410384758

Courpasson D. \& Dany F. (2009). Cultures of Resistance in the Workplace. In S. R. Clegg \& M. Haugaard (Eds.), The SAGE Handbook of Power (332-347). Inglaterra: editorial SAGE.

Crozier, M. \& Friedberg, E. (1990). El actor y el sistema. México: Alianza.

Dahl, R. (1957). The concept of power. In Department of political Science (201-215). EUA: Yale University.

Deetz, S.; Tracy, S.; \& Simpson, J. (2000). Leading Organizations Through Transition. Comunication and culture change. USA: Sage Publications, Inc.

Digeser, P. (2012) The Fourth face of power. In Stewart R. Clegg \& Mark Haugaard (Eds.) Power and Organizations volume I (221-250) Inglaterra: Editorial SAGE.

Foucault, M. (1988). El sujeto y el poder. Revista Mexicana de Sociología, 50(3), 3-20. https:// doi.org/10.2307/3540551
Foucault, M. (2002). Vigilar y Castigar. México: Siglo
Año 9 | N 18 Julio - Diciembre 2021 | ISSN 2314 - 3738

Erik Geovany González Cruz
Foucault, M. (2005). La hermenéutica del sujeto, Madrid-España: Ediciones Akal.

Foucault, M. (2008). La arqueología del saber. México: Siglo Veintiuno Editores.

Foucault, M. (2012). El poder, una bestia magnífica sobre el poder, la prisión y la vida. México: Siglo Veintiuno Editores.

Gros, F. (2005). Le gouvernement de soi. En Sciences Humaines, 3(may-june). https://www. scienceshumaines.com/le-gouvernement-desoi_fr_14329.html

Han, B. (2014). Psicopolítica. Neoliberalismo y nuevas técnicas de poder. España: Herder.

Han, B. (2017). Sobre el poder. España: Herder.

Hardy, C. (1994). Power and politics in organizations. In Cynthia Hardy, Managing strategic action. Mobilizing change, concepts, readings and cases, (pp. 220- 237). Londres: Sage.

Hardy, C. \& Clegg, S. R. (1996). Some dare call it power. In Clegg, Stewart R., Hardy, Cynthia \& Nord, Walter, Handbook of Organization Studies (622641). Inglaterra: Sage.

Hobbes, T. (1998). Leviathan. New York: Oxford University Press.

Locke, J. (1990). Ensayo sobre el gobierno civil. México: Ediciones Nuevomar, S.A. de C.V.

Lukes, S. (1984). Power a radical view. Hong Kong: Macmillan.

Maquiavelo, N. (1999). El príncipe. México: Millenium.

Marx, C. (1999). El capital, crítica de la economía política. Libro primero: el proceso de producción de capital I. México: Fondo de Cultura Económica, S.A. de C.V.

Munro, I. (2014). Organizational Ethics and Foucault's 'Art of Living': Lessons from Social Movement Organizations. Organization Studies, 35(8), pp. 1127-1148. https://doi. 
Año 9 | No 18 Julio - Diciembre 2021 | ISSN 2314 - 3738

Erik Geovany González Cruz

org/10.1177/0170840614530915

Rousseau, J. (1994). El contrato social. España: Edicomunicación, S.A.

Skinner, D. (2012). Foucault, subjectivity and ethics: towards a self-forming subject. Organization, 20(6), pp. 904-923. https://doi. org/10.1177/1350508412460419

Weber, M. (1995). Économie et sociéte 1. Les catégories de la sociologie. Librairie Plon. 